\title{
Private Savings and its Influence on Economic Growth in India in the Post Reform Period
}

Amika Khandelwal $^{*}$ and Joshy K J†

\begin{abstract}
Neo-Classical growth models show a clear relationship between savings and economic growth and consider savings a prerequisite for faster growth in an economy. Private savings in India have been a major contributor to total savings for several years. In this context, it is essential to investigate the long-run causality relationship between private savings and economic growth. It is also important, for their policy implications, to identify various determinants of private savings and analyse their impact in driving private savings. The study covers the period from 1991 to 2014 and uses the Engel-Granger cointegration test to find the direction of causality. To capture the degree of impact of various determinants on private savings ARDL model has been employed. The results show that growth in GDP and private savings in India are cointegrated and have a unilateral long-run relationship. It was found that changes in lending rates, causes a change in private savings. Other variables do not have a significant impact on private savings in India.
\end{abstract}

Keywords: Private saving, Household saving, Interest rates, Economic growth, Gross domestic product, Consumer price index

* Research Trainee, Fios Data Check Asia Pvt. Ltd., Alea Consulting Group, New Delhi, India; amika297@gmail.com

† Associate Professor and Head, Department of Economics, Christ University, Bengaluru, India; joshy.kj@christuniversity.in 


\section{Introduction}

Saving refers to the part of income set aside for future consumption. In India, savings are seen as a precautionary measure that gives social security to individuals. The aggregate savings of all households in a country is called the household savings or private savings. For an individual, saving is primarily the way to move incomes over time, whereas, for an economy, aggregate saving acts as the major source of domestic investment (Baliamoune \& Chowdhury, 2003). At a macro level, both developed and developing countries need to pay attention to domestic savings, as an increase in savings is considered a measure of economic progress. Most of the Post-World War II literature agrees with the belief that if the savings of a country is too low, development and growth would be impeded in a country (Deaton, 1989). Neo-classical growth models including Robert Solow's (1956) show a clear relationship between savings and economic growth which states that when domestic savings grow in a country, the domestic investment will go up which in turn leads to economic growth. Another implication of this relationship is that level of domestic savings shows how self-reliant the economy is, in turn indicating economic growth. When the government's expenditures go beyond the income generated in the country, it turns to internal borrowings to cover its expenditure before looking for external borrowings. The extent to which internal borrowings can cover government expenditure depends indirectly upon the savings of the country. External borrowings make a country more vulnerable to external shocks and result in the direct transfer of resources whereas internal borrowings, which are from individuals and institutions causes no direct real money burden.

Indian economy has witnessed a series of reforms through liberalisation, privatisation and globalisation measures since 1991. It has brought serious structural changes in the economy over the time in terms of the growth of goods and financial markets. The faster economic growth in the post-reform period has been determined by various factors such as domestic capital formation, human capital, technological progress, increase in labour force, trade openness and foreign investment (Joshy \& Hans, 2016). In fact, the increase in domestic savings has boosted the domestic 80 
investment which in turn has pushed the economic growth rate to higher margins. For instance, the average economic growth is as high as 6.9 percent in the post-reform period (1991-2014) against 4 percent during the pre-reform period (1951-1990). Domestic saving rate nearly doubled on an average to 27.8 percent from 14.9 percent during the same period. It is important to note that the structure of Indian economy has gone through a total transformation in terms of growth in private corporate sector and services sector, and there has been a significant rise and deepening of the financial sector. The domestic savings to GDP ratio (GDS-GDP ratio) has remained at around 33.3 percent during the post-reform period. Over the years, private saving has continued to dominate the share of gross domestic savings in the country. In 2014, gross domestic savings in India stood at 30.35 percent of GDP, out of which 22.06 percent was contributed by private savings, 7.11 percent by private corporate savings and 1.18 percent by public savings (RBI Database). The pace of economic growth has placed Indian economy into the cluster of fast-growing economies in the world. It is important to note that it is the private savings that contribute the most to the total savings in India. Also, there are several factors that influence private savings in an economy. Therefore, it is pertinent to look at the direction of causality between economic growth and private savings in India in the post-reform period on the one hand and the major determinants of private savings on the other.

\section{Review of Literature}

Many empirical and theoretical studies show a positive relationship between economic growth and savings. Some of the pioneer growth studies show that higher savings increase the level of capital availability in a country which leads to higher economic growth. When more capital is invested, it increases production of goods and services by way of increasing productivity (Harrod, 1939; Domar, 1946; Solow, 1956, and Lewis, 1970). The neoclassical paradigm propagated the idea that increased propensity to save and invest leads to sustained growth. This conventional wisdom has been empirically examined in several studies using appropriate quantitative tools. For instance, the short-run and long-run relationship between private savings and economic growth in 
Bahrain reveal a positive long-run relationship between the variables with significant bilateral causality between them (ElSeoud, 2014). The causality test between economic growth and private savings was found to be bi-directional (Agrawal \& Sahoo, 2005). The long-run relationship between economic growth and domestic savings in Botswana based on Harrod-Domar model exhibit a positive relationship (Jagadeesh, 2015). The long-run relationship between gross domestic savings as well as gross domestic private savings and GDP in Sri Lanka indicate a long-run unilateral relationship between gross domestic savings and gross domestic private savings and GDP where causality flows from gross domestic savings and gross domestic private savings to economic growth (Sinha, 1999).

However, it is important to mention that there are studies that refute the conventional wisdom of causality running from savings to economic growth. For instance, it is shown that growth of GDP caused growth in public and private savings in Mexico. However, reverse causality was not found (Sinha \& Sinha, 1998). A similar conclusion was found in India in terms of examining the fundamental nexus between savings and economic growth using the annual data from 1950-51 to 1998-99. It was also found that in big countries like India, higher savings do not lead to economic growth, but savings is the result of economic growth. The results show that economic growth influences savings positively (Sahoo, Nataraj, \& Kamaiah, 2001). Another research focusing on the savings-economic growth relationship in Nigeria indicated that the two variables are co-integrated and have long-run equilibrium. However, the causality runs from economic growth to savings and not vice-versa (Abu, 2010). The empirical analysis related to Cambodian economy showed that there is no causal relationship between economic growth and savings (Sothan, 2014).

A cross-country analysis across industrial countries in Asia, Latin America, Sub-Saharan Africa, and the Caribbean reveal that low growth and development in third world economies is often because of low levels of savings. When domestic savings are deficient, there would be the limited growth of their capacity in capital formation (Loayza, 2000). The causal relationship between the two variables in seven African countries indicates a long-run relationship 
between them. Further, growth rate causes growth in domestic savings (Anoruo \& Ahmad, 2001). The analysis of cause and effect relationship between savings and economic growth in advanced and developing economies reveals the existence of one way the casual relationship between gross domestic savings and GDP. However, there was no such evidence to conclude the relationship is the other way round (Misztal, 2011). It is observed that the saving behaviour shows variations across countries in country-specific studies because the socio-economic structure plays an important role in determining the saving behaviour. Therefore generalising the results of one country to another would not give a correct scenario (Deaton, 1989).

The literature on determinants of private savings focuses on studying specific factors that affect savings behaviour in different countries. It is observed that income or per capita growth is one of the most important determinants of both private and public savings across 36 Latin American countries. The government savings are not determined exogenously since economic and political factors influence it. Public savings are lower in countries where there is political instability, and high public savings can crowd out private savings. Other factors that can influence private savings are demographic structure, depth of financial sector and social security expenditure (Edward, 1996). The study analysing the determinates of private savings across the world shows that income, inflation and fiscal policy have a positive impact on the rate of private savings whereas other factors such as financial liberalisation and dependency ratio have a negative impact on the same (Loayza, Schmidt-Hebbel, \& Servén, 2000).

The study on Bangladesh economy reveals that total savings were found to be dependent on GDP growth rate, real interest rate, bank density and dependency ratio. The results establish a stable and long-run equilibrium between total savings rate, economic growth, banking density, interest rates, dependency ratio and foreign savings. Dependency ratio had a negative impact on total savings. Matching results were found in case of private savings too (Agrawal \& Sahoo, 2005). In Thailand, economic growth, inflation and terms of trade have a significant positive effect on private savings and increase in the old and young population dependent 
on the working class has a negative impact on private savings. Besides, the availability of bank credits tends to shrink household savings (Jongwanich, 2009). Some of the studies have attempted to link the age structure of a country as an important factor determining national savings. The life-cycle hypothesis (Modigliani, 1966) reveals the importance of demographic structure on saving levels. In four Pacific Island countries, the empirical relationship examined through pooled and country-specific regression analysis is consistent with the life-cycle hypothesis (Gani \& Yasin, 2010). The consumption pattern of the community is regarded as a very crucial determinant of a developing country (Corbo \& Schmidt-Hebbel, 1991). Studies are pointing out that the rise in public saving does not mean an equal reduction in private saving. Higher public saving is offset only in part by a decline in private saving. The research on private saving in Turkey discards the crowding out effect of private savings because of government savings (Ozcan, Gunay, \& Ertac, 2003). Some of the studies have proposed that financial sector reforms in different countries have affected the saving patterns in different ways. Financial reforms may increase the level of savings by broadening the range of instruments available and increasing the expected return through higher real interest rates and reduced risks, as deeper markets make financial assets more liquid. (Kelly \& Mavrotas, 2003). However, certain researchers argue that financial reforms may lead to a reduction in savings. It is possible through the reduction in liquidity constraints due to factors like improved access to consumer credit (Chowdhury, 2003).

In this study, the determinants of private savings have been identified on the basis of available literature related to the topic. They include GDP per capita, dependency ratio, lending rates and bank density. These factors have played a significant role in the context of other countries as well. Lending rate is the rate charged by financial institutions for their lending operations which has a direct impact on household savings. Per capita GDP is a standard determinant of saving which implies the share of goods and services produced per person in the economy. It is calculated by dividing the GDP of a country with the population of the country. Most of the related researches prove its positive relationship with savings. Dependency ratio tells the proportion of the population 84 
who do not fall under the workforce and is dependent on the working-age. Majority of the available literature shows its negative correlation with private savings. The number of bank branches in the country is taken as a measure of bank density, and it is said to have a positive relationship with private savings. With economic reforms, the number of bank branches in India has increased, improving bank accessibility, making it a very important variable.

\section{Research Problem}

The level of domestic savings is considered to be an important prerequisite to faster economic growth. It means that higher saving rate is a major determinant of economic growth in countries like India. Though a good percentage of literature available show a positive relationship between domestic savings and economic growth, there is evidence in research that negates the relationship between them. It is observed that the socio-economic structure plays an important role in determining the saving behaviour of people in different countries. The analysis of the economic data of different countries varies in terms of institutional aspects, structural aspects and quality of data. Therefore, generalising the results derived from one country and applying it to another country would give a flawed result (Deaton, 1989). Although, it is a fact that there is a certain relationship between domestic savings and economic growth, the direction of correlation cannot be determined without analysing it carefully. In India, domestic savings are considered to be a crucial factor determining the level of economic growth. With the introduction of economic reforms in the Indian economy in 1991, the domestic saving levels have gone up due to different factors. In India, private savings has always been a major contributor to total savings. Therefore, it is very significant to study the causality between private savings and economic growth in India in the post-reform period. Also, the identification of major determinants of private savings and the analysis of the extent of their influence on private savings will add more knowledge to existing literature. 


\section{Objectives}

The major objectives of the study are given below:

- To estimate the direction of causality between private savings and economic growth in India in the post-reform period

- To identify the major determinants of private savings in India and examine their impact on private savings

\section{Hypotheses}

$\mathrm{H}_{01}$ : There doesn't exist a unilateral causal relationship between economic growth and private savings

$\mathrm{H}_{02}$ : There doesn't exist any long-run dynamic relationship between private savings and its determinants

\section{Methodology}

The research is quantitative and is based on the secondary data collected from the official websites of Reserve Bank of India and Planning Commission. Data is taken from authentic sources such as the Economic Survey of India and National Sample Survey Office - Ministry of Statistics and Program Implementation. The time frame selected for this analysis is the years immediately after the post-reform period ranging from 1991 to 2014. The economic growth is measured by the real gross domestic product (GDP) of the economy. The nominal values are converted into real with the base year 2011-12. The conversion of nominal into real is done by splicing method. For the calculation of real GDP, nominal GDP is divided by GDP deflator. Nominal private savings is divided by the Consumer Price Index (CPI) to derive the values of private savings at constant prices. Also, per capita GDP is divided by CPI to convert it into constant values. The important determinants of private savings identified through the available literature include prime lending rates, bank density, GDP per capita and dependency ratio. The total number of bank branches is used as a proxy to measure bank density in the country. 


\section{Empirical Analyses and Findings}

The first objective associated with the causality between economic growth and private savings has been attained through the EngelGranger test. The second objective related to the impact of various determinants of private savings has been obtained through Auto Regressive Distributed Lag (ARDL) model.

\section{The Direction of Causality between Economic Growth and Private Savings}

Engel-Granger cointegration test is used to check whether the variables are cointegrated when the data is not stationary at order 0 . The required condition is that the variables should become stationary at level 1 , which means the variables should be in I(1) series. Then if the residual series obtained by regressing the two variables are stationary at $I(0)$, then it can be said that the two variables are cointegrated and that both the variables have a longrun relationship. The idea is that if two or more series are individually integrated at I(1) but some linear combination of them has a lower order of integration, that is $\mathrm{I}(0)$ then the series is said to be cointegrated. The linear combination is generally taken as the residual series that is obtained by regressing the variables.

To detect the speed at which disequilibrium in the economy is corrected; Error Correction Mechanism (ECM) is used. ECM exists only if the two variables are cointegrated. The coefficient of ECM ranges from +1 to -1 , which shows the speed of correction. A positive ECM value implies that the two variables will not converge in the long-run and a negative ECM shows that there will be a convergence in the long-run which means the two variables will a have an equilibrium point. It also helps in avoiding the possibility of a spurious causal relationship.

There are various tests to check the stationarity of time-series data of which the most commonly used one is Augmented Dickey-Fuller test. The test for stationarity in a variable is called unit root test. The null hypothesis states that the data has a unit root which means the data is not stationary. The alternate hypothesis states that the data does not have a unit root, which implies the data is stationary. The study deals with two macroeconomic variables for analysis - private savings and gross domestic product. In 
order to check the bivariate causal relationship between the two, unit root test is run to check whether data is stationary at $\mathrm{I}(0)$ level or I(1) order. The results of ADF test show that the data is nonstationary at $\mathrm{I}(0)$. Therefore the data is converted into a $\log$ and then checked for stationarity at $\mathrm{I}(1)$. The probability values for both the variables are below 0.05 for I(1) $\log$ series. Thus it is not possible to accept the null hypothesis. This indicates that private savings and the Gross Domestic Product becomes stationary at I(1) level (Table 1).

Table 1 Augmented Dickey-Fuller Test- Unit root test

\begin{tabular}{lcc}
\hline Name of the variables & Probability Values \\
\hline & $\mathrm{I}(0)$ & $\mathrm{I}(1)$ \\
Private Savings & 0.94 & 0.30 \\
GDP & 0.98 & 0.66 \\
Log Private Savings & 0.88 & 0.01 \\
Log GDP & 1 & 0.01 \\
\hline
\end{tabular}

Level of significance at $5 \%$

Source: By Calculation

After checking for the order of integration at which the data becomes stationary, Engle-Granger cointegration test is used to examine whether the two variables are co-integrated with a common trend. For this purpose, simple OLS is run by taking the log of private savings as dependent variable and log of GDP as the independent variable. The residual series so obtained is named (U1). Similarly, another residual series (U2) is obtained by taking the log of GDP as dependent and log of private savings as the independent variable. Then the two error or residual series is tested for the presence of unit root. As shown in table 2, the residual series $\mathrm{U} 1$ is stationary at $1(0)$ because the probability value is less than 0.05 which means that the null hypothesis of unit root test is rejected. The probability value of U2 series, when tested for a unit root is 0.22 , which means that $\mathrm{U} 2$ series is not stationary (Table 2). 
Table 2 Engle-Granger Cointegration Procedure: Unit Root Tests for the Error Series

\begin{tabular}{lll}
\hline Dependent Variable & Independent Variable & P-value for residual series \\
\hline Log Pvt Savings & Log GDP & $0.011(\mathrm{U} 1)$ \\
Log GDP & Log Pvt Savings & $0.22(\mathrm{U} 2)$ \\
\hline
\end{tabular}

Level of significance at $5 \%$

Source: By Calculation

The next step is to look into the error correction mechanism. It shows the speed of adjustment of the model during a situation of disequilibrium.

Here, $Y=c+\beta x+\mu(-1)$

Where $\mu(-1)$ is the error correction term

$\mathrm{Y}=$ dependent variable that is private savings

$\mathrm{X}=$ independent variable that is Gross Domestic Product (real GDP)

The Engel-Granger cointegration results show that private savings and GDP are cointegrated, which means that there is a long-run relationship between the two variables. There is unidirectional causality that runs between private savings and real GDP. In India, growth in GDP causes growth in private savings. The Indian scenario disproves the conventional theory that savings serves as an engine of economic growth. This implies that the contribution of domestic savings to the economic growth process is still not huge in India. This result is in line with the findings that other determinants such as technological innovation, increase in labour force, human capital, foreign investment, and trade openness play a significant role in driving the economy (Joshy \& Hans, 2016).

Table 3 Error Correction Mechanism

\begin{tabular}{llll}
\hline Variable Name & Coefficient & T-Ratio & P-Value \\
\hline Constant & -1.35 & -6.428 & $2.87 \mathrm{e}-06$ \\
Log GDP & 1.11 & 35.24 & $1.78 \mathrm{e}-19$ \\
$\mu(-1)$ & 0.75 & 4.571 & 0.0002 \\
\hline
\end{tabular}

R- Square- 0.8952, Durbin-Watson- 1.62

Source: By Calculation 
The value of error correction term is 0.75 , and the probability value is 0.0002 which is significant. The lower R Square value (0.89) than Durbin-Watson statistic (1.62) rules out the possibility of spurious regression result. Since Durbin-Watson statistic is close to 2, there would be a negligible serial autocorrelation problem. The positive Error Correction term shows that private savings and GDP will never converge in the long-run. They will rather diverge in the long-run, although both of them will move together in the same direction.

\section{The Impact of Various Determinants on Private Savings}

Auto Regressive Distributed Lag model (ARDL) is used to check the significance of the factors when the data is stationary at different levels of integration. In other words, this model is used when some variables are stationary at $\mathrm{I}(0)$, and some others are stationary at I(1), but none should be I(2) series. ARDL model takes into account ' $n$ ' number of lags. The best-fit model is the one that has the lowest Akaike Information Criterion (AIC) and Schwartz Information Criterion (SIC). The variables with the probability value less than 0.05 are the significant variables. Once the best model with a certain number of lags is found, the next step is to check for serial correlation through LM test. The null hypothesis of this test states that there is a serial correlation. If the Chi-Square value is less than 0.05 , then the null hypothesis is rejected otherwise accepted. The stability of the complete model is checked through CUSUM test.

The ARDL model is used through simple OLS since all the variables are not stationary at $\mathrm{I}(0)$. The simple regression equation is given as,

Private savings $=\beta 1+\beta 2$ (dependency ratio) $+\beta 3$ (number of branches) $+\beta 4$ (GDP per capita) $+\beta 5$ (lending rates)

In this analysis, private savings is the dependent variable and other variables such as dependency ratio, number of branches, GDP per capita and lending rates are independent variables. These variables are converted into the log to reduce the variation between them. Based on ARDL analysis the best-fit model for the study is the one with a number of lag order two. The significant 
determinants of private savings can be identified on the basis of probability values.

Table 4 ARDL model- Probability values of the variables with lag 1 and lag 2

\begin{tabular}{lll}
\hline Name of the Variables & P-value of lag 1 & P-value of lag 2 \\
\hline Private Savings & 0.0092 & 0.018 \\
D (Dependency Ratio) & 0.06 & 0.7 \\
\hline D (Bank Density) & 0.24 & 0.25 \\
D (GDP per capita) & 0.88 & 0.10 \\
D (Prime Lending Rates) & 0.00 & 0.01 \\
Dependency ratio & 0.00 & - \\
Bank Density & 0.00 & - \\
GDP per capita & 0.03 & - \\
\hline
\end{tabular}

Level of Significance- 5\%

Akaike info criterion- 2.34

Breusch-Godfrey Serial Correlation LM Test- Chi-Square (2) - 0.02

R-squared value -0.73

Durbin-Watson Test - 1.96

F-statistics probability- 0.02

Source: By Calculation

The ARDL model with two lags had the lowest AIC value amongst the models with lags 1 to 6 . All five variables such as private savings, dependency ratio, number of bank branches, per capita GDP and prime lending rates are significant against their first lag which means that each of these variables depends on its previous year values. Dependency ratio, bank density and GDP per capita show insignificant $p$-values. It implies that these variables do not affect household savings in India. It is only the lending rates that show a significant $\mathrm{p}$-value. This means that any changes in lending rates will affect savings of individual, positively or negatively. The LM test confirms that the model does not have serial correlation problem since the chi-square probability value is 0.02 , which is significant.

The stability of the model is graphically given through the result of CUSUM test below. 


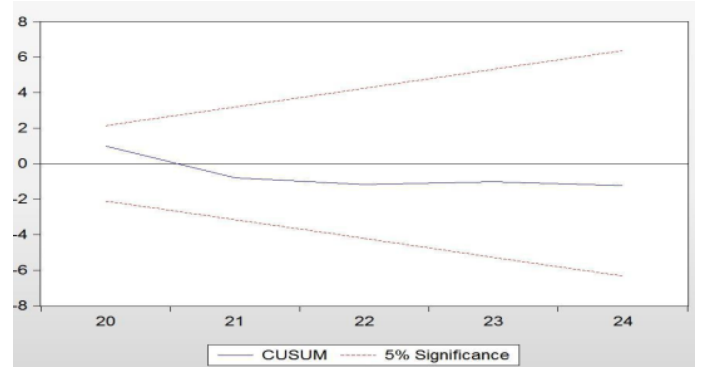

Fig 3 Stability of the model through CUSUM test

The above figure depicts the stability of the model, tested through CUSUM test. Two-sided cumulative sum (CUSUM) chart detects the shift on either side using a V-mask, instead of control limits in one-sided CUSUM tests in order to determine an out-of-control situation. The V-mask standardises the deviations from the target value and plots the deviations from this value. According to CUSUM test, the model is stable, and it is significant at 5 percent level.

\section{Policy Recommendations}

The study analyses the direction of causality between private savings and economic growth in India. Using the time-series data from 1991-2014, the Engel-Granger cointegration test is applied to discover the causality relationship between the two variables. The result indicates that these variables have a long-run relationship which implies that any change in the gross domestic product will cause a change in private savings. Therefore, the argument of the conventional neo-classical growth theories that aggregate saving is the driver of economic growth is proved false in the context of India. It highlights the need for focusing primarily on increasing the gross domestic product of the country through different ways. Since the growth of private saving is a very crucial determinant of economic growth, the economic policies can't be driven with a compromise on the short-run economic growth. Therefore, the government policies should be carried over with a positive impact on the determinants of economic growth such as domestic investment, improvement in human capital and technology, 
increase in labour force and increase in foreign capital inflow. These factors will help in stimulating economic growth by which individual saving will also accelerate. It can also be viewed from another angle. Though the domestic savings show a considerable increase in the post-reform period, it is still inadequate to feed the investment demand in the country which results in an overdependence on foreign investment inflow. It confirms the findings that external sector determinants such as foreign trade and foreign investments have started playing a key role in determining the economic growth in the post-reform period (Joshy \& Hans, 2016).

With regard to the factors affecting private savings in India, it is proved that out of the four factors only lending rates have significant effects on private savings. The other three factors namely the dependency ratio, GDP per capita and bank density, do not really affect savings behaviour of Indian households. Therefore, the study highlights that maintaining lending rates at appropriate levels is very crucial in enhancing private saving levels in the country.

\section{Scope of further Research}

The study has looked into the causality relationship between private savings and economic growth on the one hand and analysed the impact of major determinants on private savings in India. The findings and the policy suggestions that have come out of this study have far-reaching impact. However, one way of broadening the horizon of this study is by bringing the other two types of savings-public and private corporate savings- under the purview of the analysis. If we take into account all the three components of saving and examine the causality relation with economic growth, the results can be varied, or it can be made comparable through a separate analysis of all three of them. In addition, there can be a number of determinants of private saving which can alter the results in the context of the changing economic scenario. Besides, the study can be extended to the pre-reform period for facilitating comparison and drawing conclusions more fruitfully. 


\section{References}

Abu, N. (2010). Saving-economic growth nexus in Nigeria, 1970-2007: Granger causality and co-integration analyses. Review of Economic and Business Studies, 3(1), 93-104.

Agrawal, P., \& Sahoo, P. (2005). Savings and growth in Bangladesh. The Journal of Developing Areas, 42(2), 89-110.

Anoruo, E., \& Ahmad, Y. (2001). Causal relationship between domestic savings and economic growth: Evidence from seven African countries. African Development Review, 13(2), 238-249.

Baliamoune, M. N., \& Chowdhury, A. R. (2003). The long-run behaviour and short-run dynamics of private savings in Morocco. Savings and Development, 27(2), 135-160.

Case study of Bahrain. Global Journal of Commerce and Management Perspective, 3(1), 1-7.

Corbo, V., \& Schmidt-Hebbel, K. (1991). Public policies and saving in developing countries. Country Economics Department- The World Bank, WPS no. 574.

Deaton, A. (1989). Savings in developing countries: Theory and review. Proceedings of the World Bank Annual Conference on Development Economics, 61-96.

Edward, S. (1996). Why are Latin America's savings rates so low? - An international comparative analysis. Journal of Development Economics, 51(1), 5-44.

El-Seoud, D. M. (2014). Testing the relationship between private savings and economic growth:

Gani, A., \& Yasin, J. (2010). Demographic structure and private savings in selected countries of the Oceania region. Savings and Development, 34(2), 253- 267.

Jagadeesh, D. (2015). The impact of savings in economic growth: An empirical study based on Botswana. International Journal of Research in Business Studies and Management, 2(9), 10-21.

Jongwanich, J. (2009). The determinants of household and private savings in Thailand. Applied Economics, 42(10), 965-976.

Joshy, K. J., \& V. Basil Hans. (2016). Identifying the key determinants of economic growth in the post-reform period in India. FORUM: South Asian Perspectives on Management \& Social Sciences, 2(1), 20-32.

Kelly, R., \& Mavrotas, G. (2003). Savings and financial sector development: Panel cointegration evidence from Africa. World 
Institute for Development Economics Research Discussion Paper, No. 2003/12.

Loayza, N., Schmidt-Hebbel, K., \& Servén, L. (2000). What drives private savings across the world?. The Review of Economics and Statistics, 82(2), 165-181.

Misztal, P. (2011). The relationship between savings and economic growth in countries with different level of economic development. Financial Internet Quarterly, 7(2), 17-29.

Norman Loayza, K. S.H. (2000). Saving in developing countries: An overview. The World Bank Economic Review, 14(3), 393-414.

Ozcan, K. M., Gunay, A., \& Ertac, S. (2003). Determinants of private savings behaviour in Turkey. Applied Economics, 35(12), 1405-1416.

Sahoo, P., Nataraj, G., \& Kamaiah, B. (2001). Savings and economic growth in India: The long-run nexus. Savings and Development, 25(1), 67-80.

Sinha, D. (1999). Saving and economic growth in Sri Lanka. Indian Journal of Applied Economics, 8(3), 163-174.

Sinha, T., \& Sinha, D. (1998). Cart before the horse? The saving-growth nexus in Mexico. Economics Letters, 61, 43-47.

Sothan, S. (2014). Causal relationship between domestic saving and economic growth: Evidence from Cambodia. International Journal of Economics and Finance, 6, 213-220. 